\title{
PEACE ON THE
}

KOREAN PENINSULA

AND EAST ASIA 
The Institute of Southeast Asian Studies was established as an autonomous organization in 1968. It is a regional research centre for scholars and other specialists concerned with modern Southeast Asia, particularly the many-faceted problems of stability and security, economic development, and political and social change.

The Institute's research programmes are the Regional Economic Studies (RES, including ASEAN and APEC), Regional Strategic and Political Studies (RSPS), and Regional Social and Cultural Studies (RSCS).

The Institute is governed by a twenty-two-member Board of Trustees comprising nominees from the Singapore Government, the National University of Singapore, the various Chambers of Commerce, and professional and civic organizations. An Executive Committee oversees day-to-day operations; it is chaired by the Director, the Institute's chief academic and administrative officer. 
Singapore Lecture

27 November 2000

\section{PEACE ON THE \\ KOREAN PENINSULA \\ AND EAST ASIA}

Kim Dae-jung

Institute of Southeast Asian Studies 
Published by

Institute of Southeast Asian Studies

30 Heng Mui Keng Terrace

Pasir Panjang

Singapore 119614

Internet E-mail: publish@iseas.edu.sg

World Wide Web: http://www.iseas.edu.sg/pub.html

(1) 2001 Institute of Southeast Asian Studies, Singapore

\section{ISEAS Library Cataloguing-in-Publication Data}

Kim, Dae-jung, 1925-

Peace on the Korean Peninsula and East Asia.

(Singapore lecture series, 0129-1912; 19)

1. Korean reunification question (1945-)

2. Korea (South)-Politics and government-1988-

3. Korea (South)-Relations-Korea (North)

4. Korea (North)-Relations-Korea (South)

I. Title

DS501 1597 no. 19

2001

sls2001003031

ISBN 981-230-118-6 (soft cover)

ISSN 0129-1912

All rights reserved. No part of this publication may be reproduced, translated, stored in a retrieval system, or transmitted in any form or by any means, electronic, mechanical, photocopying, recording or otherwise, without the prior permission of the Institute of Southeast Asian Studies.

Typeset by International Typesetters Pte Lid Printed in Singapore by Seng Lee Press Pte Ltd 